\title{
Characterization of Eucalyptus maidenii Timber for Structural Application: Physical and Mechanical Properties at Two Moisture Conditions
}

\author{
Marta Cristina de Jesus Albuquerque Nogueira ${ }^{1}$, Victor Almeida De Araujo ${ }^{2 *}$, Juliano Souza Vasconcelos ${ }^{3}$, \\ José Nilton da Cruz ${ }^{4}$, Julio Cezar Souza Vasconcelos ${ }^{5}$, Fabio Prataviera ${ }^{5}$, André Luis Christoforo ${ }^{6}$, Francisco \\ Antonio Rocco Lahr ${ }^{7}$
}

(1) Federal University of Mato Grosso (UFMT), Department of Architecture, Av. Fernando Corrêa da Costa, BR-78060900 Cuiabá/MT, Brazil; (2) Research Group on Development of Lignocellulosic Products (LIGNO), Rua Geraldo Alckmin 519, BR-18409010 Itapeva/SP, Brazil; (3) São Paulo State University, Faculty of Agricultural Sciences (FCA-UNESP), Av. Universitária 3780, BR-18610034 Botucatu/SP, Brazil; (4) Federal University of Mato Grosso (UFMT), Department of Statistics, Av. Fernando Corrêa da Costa, BR-78060900 Cuiabá/MT, Brazil; (5) University of São Paulo (ESALQ-USP), Department of Exact Sciences, Av. Padua Dias 11, BR-13418900 Piracicaba/ SP, Brazil; (6) Federal University of São Carlos (UFSCar), Department of Civil Engineering, Rod. Washington Luís, BR-13565905 São Carlos/SP, Brazil; (7) University of São Paulo (EESC-USP), Department of Structures Engineering, Av. Trabalhador Sãocarlense 400, BR-13566120 São Carlos/SP, Brazil;

* Correspondence: e-mail: engim.victor@yahoo.de
Citation: NOGUEIRA MCJA, DE ARAUJO VA, VASCONCELOS JS, DA CRUZ JN, VASCONCELOS JCS, PRATAVIERA F, CHRISTOFORO AL, LAHR FAR 2018 Characterization of Eucalyptus maidenii Timber for Structural Application: Physical and Mechanical Properties at Two Moisture Conditions. South-east Eur for 9 (2): 141-146. DOI: https://doi.org/10.15177/seefor.18-10

Received: 15 Mar 2018; Revised: 14 Jun 2018; 2 Jul 2018; Accepted: 6 Jul 2018; Published online: 7 Aug 2018

\begin{abstract}
Background and Purpose: Eucalypt is an important raw material source of several industrial purposes. However, some eucalypt essences are still underutilized, possibly due to the lack of more embracing information about their properties. In this way, Eucalyptus maidenii species has presented a wide potential, and its lumber utilization is somewhat interesting. Nevertheless, a complete determination of its physical and mechanical properties, as carried out in this paper, certainly could encourage its popularization in construction.

Materials and Methods: Eucalyptus maidenii evaluation included two physical and fourteen mechanical parameters, regarding standard documents from Brazilian National Standards Organization (ABNT) and American Society of Testing Materials (ASTM). Thus, a simple comparison was established concerning the moisture content of wood samples, which were evaluated through two conditions: $30 \%$ as the initial level and a standard at $12 \%$. All results were statistically evaluated by t-test. In sixteen parameters, 310 determinations were carried out.

Results: Half of mechanical properties presented significant changes in their resistances with the analysed moisture reduction. Modulus of rupture in static bending and in perpendicular compression, modulus of elasticity in perpendicular compression, strength in tangential cleavage, shear stress, and perpendicular and parallel hardnesses increased their resistances when the moisture content was reduced from $30 \%$ to $12 \%$, that is, from green to dried standard stable point. Bulk density was also changed in the evaluated condition, decreasing to a smaller value. Volumetric mass density, modulus of rupture in parallel compression and in parallel and perpendicular tensiles, as well as modulus of elasticity in static bending and in parallel compression and tensile, and tangential toughness did not show any alteration in their values with this studied condition.

Conclusions: Lumber for civil construction needs to be suitable for efficient application, with air equilibrium, generally at $12 \%$ of moisture content as international normative documents require. As part of this, mechanical and physical properties/parameters were studied to characterize Eucalyptus maidenii wood regarding moisture content. The results obtained indicate the use of this essence from planted forests for structural purposes in construction.
\end{abstract}

Keywords: Maiden's Gum, wood density, strength modulus, cleavage, shear stress, hardness, toughness 


\section{INTRODUCTION}

Eucalyptus maidenii F. Muell is commercially known as Maiden's Gum [1] or eucalypt maiden [2], as well as being widely recognized as "maidene eucalypt" in Latin American markets. This species occurs naturally in high-quality closed forests on sheltered slopes and gullies in good soils [1], among latitudes 34 and $39 \mathrm{~S}$ in altitudes from 230 to 915 meters, and its origin is along the Australian regions of southern New South Wales and northeastern Victoria [1, 3]. Maiden's Gum species is also found in Brazil [4,5], Uruguay $[6,7]$, New Zealand [8-10], India [11], Portugal [5], Italy, Iberian Peninsula, Kenya, Malawi, Burundi [1], Tanzania [12], Uganda [13], Rwanda [14], etc. Eucalyptus maidenii is a tall to very tall forest tree usually 30 to 45 meters in height with a diameter of up to 2.5 meters, whose bark is smooth, whitish or cream, decorticating in strips to ground level, or sometimes with a short stocking of undecorticated rough bark [15]. Maiden's Gum trees could provide acid oils from their leaves [16] and their fruits [17] or medicines from their leaves [11], as well as extracts from their barks [18, 19]. Wood from Maiden's Gum has sapwood susceptible to Lyctus borer attack, and its light brown heartwood with pinkish to orange tints is hard, moderately strong and durable, coarse, uniform in texture, and with grain that is sometimes interlocked $[1,15]$. Eucalyptus maidenii is usually applied for fuelwood [12], tannins [20], essential oils [20-22], pulp and paper [1, 8, 23], etc.

Maiden's Gum wood presents some good mechanical properties [24] and for that reason is recommended for heavy construction [1], products from sawmills, posts and poles [3]. Due to the Eucalyptus maidenii structural potentiality as sawn wood, the study aimed to explore physical and mechanical properties of this wood species at two different stable moisture contents, $30 \%$ and $12 \%$, evaluating its reduction effect in a point close to the fiber saturation and other with respect to normative documents for structural applications.

\section{MATERIALS AND METHODS}

The wood species studied here was Eucalyptus maidenii, whose logs were collected in two Brazilian cities in São Paulo State to generate the wooden samples used in the tests (Table 1). A universal testing machine was used to perform the evaluation of properties.
To evaluate Eucalyptus maidenii as structural lumber, sixteen physical and mechanical properties were performed with small clear specimens, whose selection was based on defect absence. This testing followed the prescriptions of Brazilian ABNT NBR 7190:1997 [25] and American ASTM D-143-14:2014 [26] standards for the following properties: density (bulk and volumetric mass); perpendicular and parallel compressions, perpendicular and parallel tensiles, and static bending (in modulus of rupture and elasticity parameters); shear stress; cleavage (tangential); hardness (parallel and perpendicular); and toughness (tangential). Tangential orientation was selected due to strength in parallel direction to growth rings, and supported by an observation by Stolf et al. [27] claiming that there is no significant difference between radial and tangential toughnesses for dicotyledonous trees.

Similarly to Lahr et al. [28] and Nogueira et al. [29] studies, the samples used in these sixteen tests were prepared and conditioned for stabilization in both moistures at green $(30 \%)$ and standard point $(12 \%)$ in the Laboratory of Wood and Timber Structures (LaMEM) at the School of Engineering of São Carlos from the University of São Paulo (USP-EESC), São Carlos, Brazil. Furthermore, 310 determinations (or repetitions) were carried out in the aforementioned sixteen physical-mechanical parameters for the evaluation of Eucalyptus maidenii.

Ultimately, the obtained results by property were statistically verified with the analysis of $\mathrm{t}$-test according to the significance level of $5 \%(P$-value $<0.05)$ to investigate the moisture content influence in the observed sixteen physical-mechanical properties of Eucalyptus maidenii wood. Through the hypothesis formulation, a P-value higher than the significance level implies accepting the null hypothesis, whose means of the two groups of moisture are equivalent, or rejecting it otherwise when the means are not equivalent.

\section{RESULTS}

Physical properties of density were verified and the obtained results are described in Table 2 with their respective statistical analyses.

Apart from the physical properties, 14 mechanical parameters were demonstrated with their statistical analyses (Tables 3, 4, and 5). Table 3 showed modulus of rupture results.

TABLE 1. Aspects of the Eucalyptus maidenii origin.

\begin{tabular}{ccccc}
\hline Log Amount & $\begin{array}{c}\text { Beam Amount } \\
\text { (unit) }\end{array}$ & $\begin{array}{c}\text { Age } \\
\text { (year) }\end{array}$ & $\begin{array}{c}\text { Diameter } \\
(\mathrm{m})\end{array}$ & Brazilian Region \\
\hline 1 & 2 & 28 & 0.260 & Rio Claro (SP) \\
2 & 2 & 28 & 0.255 & Manduri (SP) \\
3 & 2 & 28 & 0.240 & Rio Claro (SP) \\
4 & 2 & 28 & 0.230 & Rio Claro (SP) \\
5 & 2 & 28 & 0.255 & Rio Claro (SP) \\
\hline
\end{tabular}


Table 4 indicated the obtained results and statistical analysis for modulus of elasticity of Eucalyptus maidenii wood.

Table 5 showed the obtained results for the last five strength properties, that is, shear stress, tangential cleavage, perpendicular and parallel hardnesses, and tangential toughness of the studied Eucalyptus maidenii wood species.

All listed tests were performed, revealing the successful obtaining of sixteen studied properties (Tables 2 to 5 ).

TABLE 2. Eucalyptus maidenii wood densities.

\begin{tabular}{|c|c|c|c|c|c|}
\hline Characteristics & $\begin{array}{l}\text { MC } \\
(\%)\end{array}$ & n & $M_{D}$ & sd & P-value \\
\hline \multirow{2}{*}{ Bulk Density $\left(\mathrm{g} \cdot \mathrm{cm}^{-3}\right)$} & 30 & 10 & 1.19 & 0.08 & \multirow{2}{*}{0.0003} \\
\hline & 12 & 10 & 0.92 & 0.16 & \\
\hline \multirow{2}{*}{ Volumetric Mass Density $\left(\mathrm{g} \cdot \mathrm{cm}^{-3}\right)$} & 30 & 10 & 0.71 & 0.15 & \multirow{2}{*}{0.6277} \\
\hline & 12 & 10 & 0.74 & 0.12 & \\
\hline
\end{tabular}

TABLE 3. Eucalyptus maidenii wood modulus of rupture.

\begin{tabular}{|c|c|c|c|c|c|}
\hline Characteristics & $\begin{array}{l}\text { MC } \\
(\%)\end{array}$ & $\mathbf{N}$ & $M_{R}$ & sd & P-value \\
\hline Parallel Compression (MPa) & 30 & 10 & 43.8 & 6.4 & 0.0978 \\
\hline \multirow{2}{*}{ Perpendicular Compression (MPa) } & 30 & 9 & 1.7 & 0.3 & \multirow{2}{*}{0.0032} \\
\hline & 12 & 10 & 3.7 & 1.6 & \\
\hline Parallel Tensile (MPa) & 12 & 8 & 83.7 & 29.9 & 0.4731 \\
\hline \multirow{2}{*}{ Perpendicular Tensile (MPa) } & 30 & 9 & 3.8 & 1.2 & \multirow{2}{*}{0.2537} \\
\hline & 12 & 9 & 4.8 & 2.2 & \\
\hline \multirow{2}{*}{ Static Bending (MPa) } & 30 & 10 & 92 & 21.5 & \multirow{2}{*}{0.0000} \\
\hline & 12 & 10 & 225 & 27.4 & \\
\hline
\end{tabular}

TABLE 4. Eucalyptus maidenii wood modulus of elasticity

\begin{tabular}{|c|c|c|c|c|c|}
\hline Characteristics & $\begin{array}{l}\text { MC } \\
(\%)\end{array}$ & $\mathbf{N}$ & $M_{E}$ & sd & P-value \\
\hline Parallel Compression (MPa) & 30 & 10 & 15564.0 & 5710.7 & 0.6302 \\
\hline \multirow{2}{*}{ Perpendicular Compression (MPa) } & 30 & 9 & 169.1 & 27.7 & \multirow{2}{*}{0.0029} \\
\hline & 12 & 10 & 368.0 & 156.1 & \\
\hline Parallel Tensile (MPa) & 12 & 8 & 18932.2 & 4411.7 & 0.2735 \\
\hline \multirow{2}{*}{ Static Bending (MPa) } & 30 & 10 & 13620.5 & 3994.8 & \multirow{2}{*}{0.1344} \\
\hline & 12 & 10 & 16024.4 & 2692.2 & \\
\hline
\end{tabular}

TABLE 5. Other strength properties of Eucalyptus maidenii wood.

\begin{tabular}{|c|c|c|c|c|c|}
\hline Characteristics & $\begin{array}{l}\text { MC } \\
(\%)\end{array}$ & n & $\mathrm{M}_{\mathrm{OP}}$ & sd & P-value \\
\hline \multirow{2}{*}{ Shear Stress (MPa) } & 30 & 10 & 11.7 & 1.9 & \multirow{2}{*}{0.0010} \\
\hline & 12 & 10 & 17.2 & 3.7 & \\
\hline \multirow{2}{*}{ Tangential Cleavage (MPa) } & 30 & 10 & 0.64 & 0.21 & \multirow{2}{*}{0.0000} \\
\hline & 12 & 10 & 1.16 & 0.22 & \\
\hline \multirow{2}{*}{ Perpendicular Hardness (kN) } & 30 & 10 & 7.34 & 1.62 & \multirow{2}{*}{0.0078} \\
\hline & 12 & 10 & 10.03 & 2.29 & \\
\hline \multirow{2}{*}{ Parallel Hardness (kN) } & 30 & 10 & 7.48 & 3.31 & \multirow{2}{*}{0.0449} \\
\hline & 12 & 10 & 10.08 & 1.69 & \\
\hline \multirow{2}{*}{ Tangential Toughness (N.m) } & 30 & 10 & 15.3 & 5.6 & \multirow{2}{*}{1.0000} \\
\hline & 12 & 10 & 15.3 & 5.6 & \\
\hline
\end{tabular}




\section{DISCUSSION}

Bulk density results indicated a decrease of $22.69 \%$ or $0.27 \mathrm{~g} \cdot \mathrm{cm}^{-3}$ in this property when the moisture contents of Eucalyptus maidenii samples were reduced from $30 \%$ to $12 \%$. In contrast, the volumetric mass density slightly increased to $4.05 \%\left(0.03 \mathrm{~g}^{-\mathrm{cm}^{-3}}\right)$ with this same situation of moisture content reduction. With the support of t-test for these densities, we verified the bulk density and rejected the null hypothesis of mean equality, because of changes in moisture content from $30 \%$ to $12 \%$ showed significant difference in the obtained means (P-value<0.05). However, volumetric mass density did not present this null hypothesis rejection, which is explained by the independence of these means in relation to this reduction (Table 2). Comparing it with literature for Eucalyptus maidenii species from New Zealand, McKinley et al. [10] obtained nominal densities for 11-year-old wood between 600 and 760 . This range is close, but lower, to the range showed in this study. This was expected, because their samples were younger than those 28-year-old woods studied here, that is, almost three times older and thus lightly denser.

Modulus of rupture results indicated increases of $9.32 \%$ or $4.5 \mathrm{MPa}$ in the parallel compression, $54.05 \%$ (or $2 \mathrm{MPa}$ ) in perpendicular compression, $20.83 \%(1 \mathrm{MPa})$ in perpendicular tensile, and $59.11 \%(133 \mathrm{MPa})$ in static bending when the moisture contents of Eucalyptus maidenii samples were reduced from $30 \%$ to $12 \%$. Even in this moisture content reduction, the parallel tensile presented a decrease of $10.58 \%$ (9.9 MPa). By the t-test analysis, we observed the perpendicular compression and static bending means and rejected the null hypothesis of equality means, whereas their means indicated significant difference when the moisture content was reduced from $30 \%$ to $12 \%$ (P-value $<0.05)$. In contrast, parallel compression, and parallel and perpendicular tensiles did not reject the null hypothesis, i.e., their means did not present significant difference with the moisture decreasing (Table 3). In their study for 11-yearold Eucalyptus maidenii wood, McKinley et al. [10] reached two times lower modulus of rupture in static bending, likely due to this younger age and lower density.

Modulus of elasticity results indicated increases of $11.02 \%$ or $2087.1 \mathrm{MPa}$ in parallel tensile and $54.05 \%$ (or $198.9 \mathrm{MPa}$ ) in perpendicular compression when the moisture contents of Eucalyptus maidenii samples were reduced from $30 \%$ to $12 \%$. In such modulus, the moisture reduction caused decreases of $7.85 \%(1133 \mathrm{MPa})$ in parallel compression, and $15.00 \%(2403.9 \mathrm{MPa})$ in static bending. The t-test analysis applied in these modulus of elasticity showed only perpendicular compression which showed a significant difference in its means when the moisture content was reduced from $30 \%$ to $12 \%$, due to the null hypothesis rejection (P-value $<0.05)$. Successively, static bending, and parallel compression and tensile did not reject this null hypothesis, and due to these properties did not present significant differences in their means (Table 4). Thus, as compared to McKinley et al. [10], for 11-year-old Eucalyptus maidenii wood also at $12 \%$ of moisture content, the obtained results were one fifth higher than their modulus of elasticity in static bending, certainly, on account of the difference of age and density found in the two studies that focused on this particular species.

When the moisture content was reduced to $12 \%$ (dried and standard point), other strength property results indicated increases in tangential cleavage, shear stress, and parallel and perpendicular hardnesses in the amount of $44.83 \%$ (0.52 MPa), 31.98\% (5.5 MPa), 25.79\% (2.60 kN), and $26.82 \%$ (2.69 kN), respectively. Tangential toughness remained stable with the same value. The application of $t$-test in tangential cleavage, shear stress, and perpendicular and parallel hardnesses showed that these properties rejected the null hypothesis of mean equality, in other words, their moisture content revealed significant differences in their means when moisture content was reduced from $30 \%$ to $12 \%$ (P-value $<0.05$ ). Only modulus of tangential toughness did not present this significant difference in its means with this moisture reduction (Table 5).

In a study about the evaluation of Eucalyptus urophylla var. maidenii clones, Beltrame et al. [24] studied wood mechanical properties at $12 \%$ of moisture content. From values of rupture and elasticity modulus (both in static bending and parallel compression), and shear stress obtained by Beltrame et al. [24], it could be verified that this clone is mechanically similar to traditional Eucalyptus maidenii timber studied here. McKinley et al. [10] evaluated hardness of Eucalyptus maidenii 11-year-old wood, but did not evaluate shared specific direction, that is, parallel or perpendicular. In both cases, the obtained hardness was superior to that showed in their study, likely, due to their younger wood samples with lower densities.

Regarding those results that showed no effect with moisture content reduction, that is, volumetric mass density (Table 2), tensile strength parallel to fibers (Table 3 ), modulus of elasticity at parallel compression to fibers (Table 4), and tangential toughness (Table 5), these situations occurred possibly due to the grouped consideration of wood samples from five different farms (Table 1), that is, four forestry areas at Rio Claro city and another at Manduri city, both in São Paulo state, Brazil. This grouping was considered regarding of the exact age and eucalypt species from these five distinct plantations from the same Brazilian state region. However, such regard revealed three negative impacts and a neutral result (toughness), in contrast to other twelve positive effects verified with moisture reduction by this grouping.

There are cases, such as the one reported by Duarte [30], that the rupture can occur in fragile mode, resulting in a lower influence of moisture content in each studied mechanical property. In addition, eventual grain deviations are very common in eucalypts such as in maidenii [31]. Therefore, these two situations can be acceptable explanations to the observed negative effects, considering that specific property improvements were not captured by statistical analysis in view of these possible anatomical factors and rupture types from testing.

By adding value to forests by means of timber production used in prefabricated components employed in low-rise timber buildings, the reduction of wood utilization from native areas is required, for example, aiming at positive effects from forest management, which include the environment, the 
landscape, and the reduction of hydrogeological hazard [32]. At the same time, the popularization and correct utilization of wood, particularly those species available in planted forests, such as Eucaliptus spp, should be intensified [33].

Thereby, the study demonstrated that clear timber without perceptible defects of Eucalyptus maidenii species could be efficiently applied for lumber-based products and raw materials for construction, furniture and other structural uses, because its mechanical properties efficiently complied with the studied structural stress strengths at standardised moisture content. Popularization and correct use of wood from planted forests [32], such as Eucalyptus maidenii, according to Fragiacomo et al. [33], can contribute to the reduction of wood utilization from native areas, offering positive effects on the environment.

\section{CONCLUSIONS}

According to the results on clear pieces without perceptible defects, Eucalyptus maidenii wood species achieved required goals for its efficient utilization in structural applications, whereas woods from five forestry areas in São Paulo state were considered.

This forestry essence is raw material easily obtained from planted forests, and such eucalypt species demonstrated improvements in half of their mechanical strengths studied, when these properties were submitted to moisture reduction from $30 \%$ of fibre saturation point to $12 \%$ of air equilibrium prescribed by international normative documents for wood application in civil construction.

\section{REFERENCES}

1. FAO 1981 Eucalypts for planting. 2nd ed. Food and Agriculture Organization of the United Nations, Rome, Italy, 677 p. URL: http://www.fao.org/3/a-ac459e.pdf (15 March 2018)

2. MAIDEN JH 1922 The forest flora of New South Wales. 1st. ed. 7 (61-70). University of Sydney Library, Sydney, Australia

3. FERREIRA M 1979 Escolha de espécies de eucalipto. IPEF (47): 1-30. URL: http://www.almanaquedocampo.com.br/ imagens/files/Eucal\%C3\%ADpto\%20escolha\%20de\%20 esp\%C3\%A9cies.pdf (15 March 2018)

4. SCHUMACHER MV, CALDEIRA MVW 2001 Biomass estimation and nutrient content of a Eucalyptus globulus (Labillardière) subspecie maidenii plantation (in Portuguese with English summary). Ciencia Florestal 11 (1): 45-53. DOI: https://doi.org/10.5902/19805098494

5. DOMINGUES RMA, SOUSA GDA, SILVA CM, FREIRE CSR, SILVESTRE AJD, PASCOAL NETO C 2011 High value triterpenic compounds from the outer barks of several Eucalyptus species cultivated in Brazil and in Portugal. Ind Crops Prod 33 (1): 158-164. DOI: https://doi.org/10.1016/i. indcrop.2010.10.006

6. PÉREZ CA, WINGFIELD MJ, ALTIER NA, SIMETO S, BLANCHETTE RA 2011 Puccinia psidii infecting cultivated Eucalyptus and native Myrtaceae in Uruguay. Mycol Prog 10 (3): 273-282. DOI: https://doi.org/10.1007/s11557-010$\underline{0698-\mathrm{X}}$

7. SOTERO M, MONZA J 2007 Micropropagation of Eucalyptus maidenii elite trees. Agrociencia 11 (1): 81-89

8. KIBBLEWHITE RP, JOHNSON BI, SHELBOURNE CJA 2000 Kraft pulp qualities of Eucalyptus nitens, E. globulus, and E. maidenii at ages of 8 and 11 years. N Z J For Sci 30 (3): 447-457

9. STACKPOLE DJ, MCCONNOCHIE RM, DUNGEY HS, LOW CB, BURDON RD, KENNEDY SG 2013 Comparative performance of Eucalyptus bicostata, E. globulus, E. maidenii and E. pseudoglobulus on three northern New Zealand sites. NZ J For Sci 43 (6): 1-10. DOI: https://doi.org/10.1186/11795395-43-6

10. MCKINLEY RB, SHELBOURNE CJA, LOW CB, PENELLUM B, KIMBERLEY MO 2002 Wood properties of young Eucalyptus nitens, E. globulus, and E. maidenii in Northland, New Zealand. N Z J For Sci 32 (3): 334-356
11. PRABHU S, VIJAYAKUMAR S, YABESH JEM, RAVICHANDRAN K, SAKTHIVEL B 2014 Documentation and quantitative analysis of the local knowledge on medicinal plants in Kalrayan hills of Villupuram district, Tamil Nadu, India. J Ethnopharmacol 157: 7-20. DOI: https://doi.org/10.1016/j. jep.2014.09.014

12. ALLEN JC 1985 Wood energy and preservation of woodlands in semi-arid developing countries. J Dev Econ 19 (1-2): 5984. DOI: https://doi.org/10.1016/0304-3878(85)90039-2

13. NYEKO P, MUTITU EK, DAY RK 2009 Eucalyptus infestation by Leptocybe invasa in Uganda. Afr J Ecol 47 (3): 299-307. DOI: https://doi.org/10.1111/i.1365-2028.2008.01004.x

14. NSABIMANA D, KLEMEDTSON L, KAPLIN BA, WALLIN G 2009 Soil $\mathrm{CO}_{2}$ flux in six monospecific forest plantations in Southern Rwanda. Soil Biol Biochem 41 (2): 396-402. DOI: https://doi.org/10.1016/i.soilbio.2008.12.004

15. BOLAND DJ, BROOKER MIH, CHIPPENDALE GM. HALL N, HYLAND BPM, JOHNSTON RD, KLEINIG DA, MCDONALD MW, TURNER JD 2006 Forest trees of Australia. 5th ed. Csiro Publishing, Collingwood, Australia, $768 p$

16. TIAN LW, ZHANG YJ, WANG YF, LAI CC, YANG CR 2009 Eucalmaidins $A-E,(+)$-oleuropeic acid derivatives from the fresh leaves of Eucalyptus maideni. J Nat Prod 72 (9): 16081611. DOI: https://doi.org/10.1021/np900290s

17. TIAN LW, ZHANG YJ, QU C, WANG YF, YANG CR 2010 Phloroglucinol glycosides from the fresh fruits of Eucalyptus maideni. J Nat Prod 73 (2): 160-163. DOI: https://doi.org/10.1021/np900530n

18. SANTOS SAO, VILLAVERDE JJ, FREIRE CSR, DOMINGUES RM, PASCOAL NETO C, SILVESTRE AJD 2012 Phenolic composition and antioxidant activity of Eucalyptus grandis, E. urograndis (E. grandis $\times E$. urophylla) and E. maidenii bark extracts. Ind Crops Prod 39: 120-127. DOI: https://doi. org/10.1016/j.indcrop.2012.02.003

19. LUIS Â, NEIVA D, PEREIRA H, GOMINHO J, DOMINGUES F, DUARTE ÂP 2014 Stumps of Eucalyptus globulus as a source of antioxidant and antimicrobial polyphenols. Molecules 19 (10): 16428-16446. DOI: https://doi.org/10.3390/ molecules191016428

20. BALACS T 1997 Cineole-rich Eucalyptus. Int J Aromather 8 (2): 15-21. DOI: https://doi.org/10.1016/S09624562(97)80020-3 
21. GUNDIDZA M, CHINYANGANYA F, MAVI S 1993 Antimicrobial activity of the essential oil from Eucalyptus maidenii. Planta Med 59 (1): 705-706. DOI: https://doi. org/10.1055/s-2006-956515

22. ROH HS, LEE BH, PARK CG 2013 Acaricidal and repellent effects of myrtacean essential oils and their major constituents against Tetranychus urticae (Tetranychidae). J Asia Pac Entomol 16 (3): 245-249. DOI: https://doi. org/10.1016/j.aspen.2013.03.001

23. RENCORET J, GUTIÉRREZ A, DEL RIO JC 2007 Lipid and lignin composition of wood from different eucalypt species. Holzforschung 61 (2): 165-174. DOI: https://doi. org/10.1515/HF.2007.030

24. BELTRAME R, PERES ML, DELUCIS RA, FREITAS DL, GATTO DA, HASELEIN CR 2015 Longitudinal growth stress and mechanical properties of wood from Eucalyptus spp. clones (in Portuguese with English summary). Matéria (Rio J) 20 (4): 1061-1074. DOI: https://doi.org/10.1590/S1517707620150004.0108

25. ABNT NBR 71901997 Design of wooden structures (in Portuguese with English summary). Brazilian National Standards Organization, Rio de Janeiro, Brazil

26. ASTM D143-14 2014 Standard test methods for small clear specimens of timber. American Society of Testing Materials, West Conshohocken, USA.

27. STOLF DO, BERTOLINI MS, ALMEIDA DH, SILVA DAL, PANZERA TH, CHRISTOFORO AL, LAHR FAR 2015 Influence of growth ring orientation of some wood species to obtain toughness. REM: Rev ESC Minas 68 (3): 265-271. DOI: https://doi.org/10.1590/0370-44672014680018
28. LAHR FAR, NOGUEIRA MCJA, DE ARAUJO VA, VASCONCELOS JS, CHRISTOFORO AL 2017 Physical-mechanical characterization of Eucalyptus urophylla wood. Eng Agric 37 (5): 900-906. DOI: https://doi.org/10.1590/1809-4430Eng.Agric.v37n5p900-906/2017

29. NOGUEIRA MCJA, ALMEIDA DH, VASCONCELOS JS, ALMEIDA TH, ARAUJO VA, CHRISTOFORO AL, LAHR FAR 2018 Properties of Eucalyptus umbra wood for timber structures. International Journal of Materials Engineering 8 (1): 12-15. DOI: https://doi.org/10.5923/i. ijme.20180801.03

30. DUARTE BB 2017 Influência de componentes químicos em propriedades mecânicas da madeira (in Portuguese with English summary). PhD thesis, School of Engineering of São Carlos, University of São Paulo, São Carlos, Brazil, 127 p

31. NOGUEIRA MCJA 1991 Indicações para o emprego de 16 espécies de eucalipto na construção civil (in Portuguese with English summary). MSc dissertation, School of Engineering of São Carlos, University of São Paulo, São Carlos, Brazil, $150 \mathrm{p}$

32. DE ARAUJO VA, GARCIA JN, CORTEZ-BARBOSA J, GAVA M, SAVI AF, MORALES EAM, LAHR FAR, VASCONCELOS JS, CHRISTOFORO AL 2017 Importance of wood from planted forests for manufacturing industry (in Portuguese with English summary). Pesq Flor Bras 37 (90): 189-200. DOI: https://doi.org/10.4336/2017.pfb.37.90.824

33. FRAGIACOMO M, RIU R, SCOTTI R 2015 Can structural timber foster short procurement chains within Mediterranean forests? A research case in Sardinia. Southeast Eur For 6 (1): 107-117. DOI: https://doi.org/10.15177/ seefor.15-09 